\title{
The Diversification of River Habitat Survey Output During the Four Seasons: Case Studies of Three Lowland Rivers in Poland
}

\author{
Marta Kiraga ${ }^{1 *}$ \\ 1 Institute of Civil Engineering, Warsaw University of Life Sciences WULS - SGGW, Poland \\ e-mail: marta_kiraga@sggw.pl
}

\begin{abstract}
The EU Water Framework Directive demands maintaining or attaining good quality of the water bodies within the territory of the member states, which is strictly connected with the planning process of the water resources management. The water management plans have to include the assessment of the water body quality condition and further propose the actions to be implemented to enhance the quality of the European water resources. In order to answer the question of whether there is a risk of failure to achieve the WFD objectives, an assessment of the current status should be carried out, followed by an estimate on how likely achieving a good water status in the future is. One of the most popular valorization methods used for the water quality assessment is the River Habitat Survey (RHS) that enables the determination of two indicators, which summarize many single basic parameters, to assess the hydromorphological properties of rivers in a numerical form. Two indices are used most widely: Habitat Modification Score (HMS), which defines the range of transformations in river morphology and Habitat Quality Assessment (HQA), which is based on the presence and diversity of natural elements of the stream and river valley. The application of the above mentioned numerical indices allows calculating the hydromorphological quality status of the studied section following the expectations of the Water Framework Directive. Five ecological classes are distinguished. RHS is described as objective, suitable for statistical analyses, multidirectional and applicative method. However, the final valorization results are strongly affected by the presence of vegetation, which varies during the whole year. This contribution describes the analysis and comparison of the RHS results over the four seasons, namely: spring, summer, autumn and winter of three small lowland rivers in Poland (Zielawa, Zwoleńka and Zagożdżonka). It was unequivocally found that the value of the HQA parameter varied during the seasons, and the changes in its numerical value mainly depended on the condition, development level of vegetation, and the number of species observed. It was demonstrated that depending on the season, the Habitat Quality Assessment variation could change in about 5\% of the maximal value, which could lead to a step from one hydromorphological class to another.
\end{abstract}

Keywords: hydromorphological state, HQA, HMS, habitat modification score, habitat quality assessment, annual variability of HQA

\section{INTRODUCTION}

The roots of the River Habitat Survey project reach the beginning of the 1990s. The main objective of the project was to establish a methodology for denoting the habitat features along the rivers in England and Wales and to evaluate the importance of wildlife on the river ecosystem. The RHS project represents two decades of research and development work. It is one of the recognised methodologies for the European Water Framework Directive implementation, which aims to bring in a new era for European water management, focusing on understanding and integrating all aspects of the water environment to be effective and sustainable (Teodosiu et al. 2003).

For many years, the water quality had been the main focus of environmental management. The most often considered issues were pollutants, acid rain, or organic inputs; however, the following decades of ecological improvements began to emphasize the significance of the river channel networks and development. 
It was noted that improving the water quality has a positive influence on the life and development of aquatic organisms such as fish; however, recolonization of the habitat by native species is not consistent across the whole river network. The quality of riverine habitats and the impact of engineering structures on the physical diversity of streams were identified as potential limitations to the species distribution and survival (Able et al. 1999; Lacoul and Freedman 2006). The evaluation of hydromorphological status is recognized as one of the supplementary criteria in ecological quality of river recognition, as well as physicochemical quality of the water (Armitage and Pardo 1995, Kemp et al. 2000, Popek and Wasilewicz 2004, Kiraga and Popek 2014.)

The RHS system serves to evaluate the hydromorphological character and habitat quality of rivers on the basis of their physical structure (Raven et al., 1999). It has four distinct components i.e., a field survey method; a computer database for entering results from survey sites; (iii) a set of methods for assessing the habitat quality; and (iv) a system for describing the level of man-made channel modification (Knehtl et al. 2017).

The hydromorphological quality of a habitat is recognized by feature diversity occurrence, including the wildlife presence, as it is derived by comparing the features observed with those recorded from rivers of similar character. The RHS method assumes systematic data collection, connected with the physical structure of watercourses within $500 \mathrm{~m}$ reach of river length. The data collection is based on a standard $500 \mathrm{~m}$ length of the river channel and includes not only its characteristics, but also land use and adjacent river corridor attributes, such as geology, slope, or distance from the source. A field survey obtains the data pertaining to both in-stream and bank features. The methodology assumes 10 spot-checks surveillance, with a 50 meters distance between each. Spot-check observations, complemented with the surveillance between them, provide an image of river values as a natural ecosystem (Fig. 1).

Two quantitative parameters are determined: HQA (Habitat Quality Assessment) and HMS (Habitat Modification Score). The HQA provides the information about the level of the naturalness of the section. Habitat Modification Score describes the modification degree of the chosen reach, i.e., whether there is a measure of the deviation of a section from its natural, intact state.

The HQA parameter permits forming a description of diversity of the naturally existing morphological elements of a river and its valley. The value of the HQA is influenced by hydraulic and granulometric parameters, such as discharge type, bedload granulation, bank and bed morphological elements naturally occurring within the channel, as well as the diversity of both water and riparian vegetation, the appearance of which is highly correlated with the season (Ferreira et al. 2011). High values of the HQA demonstrate high diversity and a significant number of natural elements in a channel and within the surrounding area.

The Habitat Modification Score parameter indicates a total degree of anthropogenic changes, including the quantity and size of particular types of water structures (dams, piers, culverts, bridges,

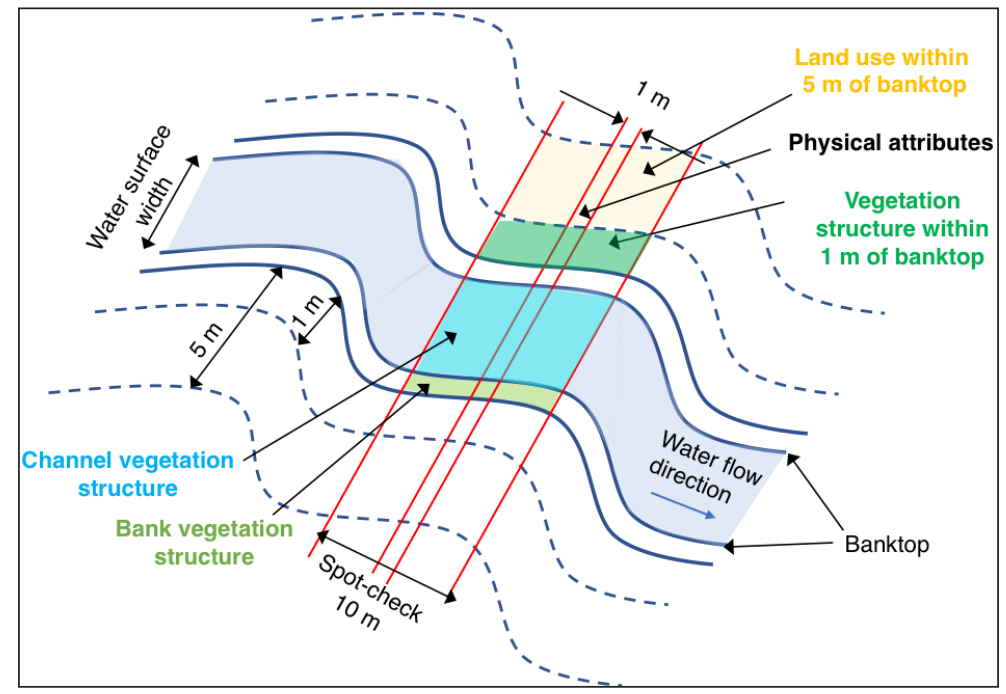

Figure 1. Dimensions of the researched sections in spot-checks 
groynes), bank profile transformations such as reinforcing, embanking, resectioning, devastation, plants mowing, as well as bottom modifications, including, among other things, reinforcing, artificial bottom material inserting, dredging, water plant carving).

The HQA and HMS numerical indices are inversely proportional; however, two ecologically similar river sections could be characterized by different anthropogenic influences. The anthropogenic transformations do not necessarily lead to a drop in the hydromorphological quality of rivers. If this was so, any modifications would be abandoned. The higher HMS value, the more durable habitat transformation, and therefore the more advanced the processes leading to distinguishing the habitat from the natural status. However, the human efforts could also lead to increasing the naturalness of the habitat (Kiraga and Popek 2014).

\section{MATERIAL AND METHODS}

Three research sections located on the Zielawa, Zagożdżonka, and Zwoleńka rivers were selected. Their common feature is that they have the character of small lowland rivers and are located in the area of central-eastern Poland (Zielawa Lublin Province, Zagożdżonka and Zwoleńka Mazowieckie Province) (Fig. 2, Fig. 3a, b, c). The different character of lowland rivers is expressed, among others, in the dynamics of flows, continuity of sediment, and the crucial role of the riverbed and floodplain vegetation.

The Zielawa River is a right tributary of the Krzna River and originates in an artificial reservoir near the village of Mosty. The reservoir abounds in various fish species and is very popular among the local anglers. The natural landscape is represented by a vast accumulation plain resulting from, among others, the influence of the river itself. Zielawa has a connection with the surrounding drainage network, especially in its upper part, which makes it difficult to determine the course of the river tributaries.

The Zielawa valley, like any river valley, is characterized by a large variety of plant communities, both eutrophic and wet, as well as dry and mesotrophic. Pine forests grow in drier areas, while in wetlands, among others, riparian alder forests with black alder are found, as a characteristic type. The valley is dominated by meadow-forest land, characterized by peat bogs

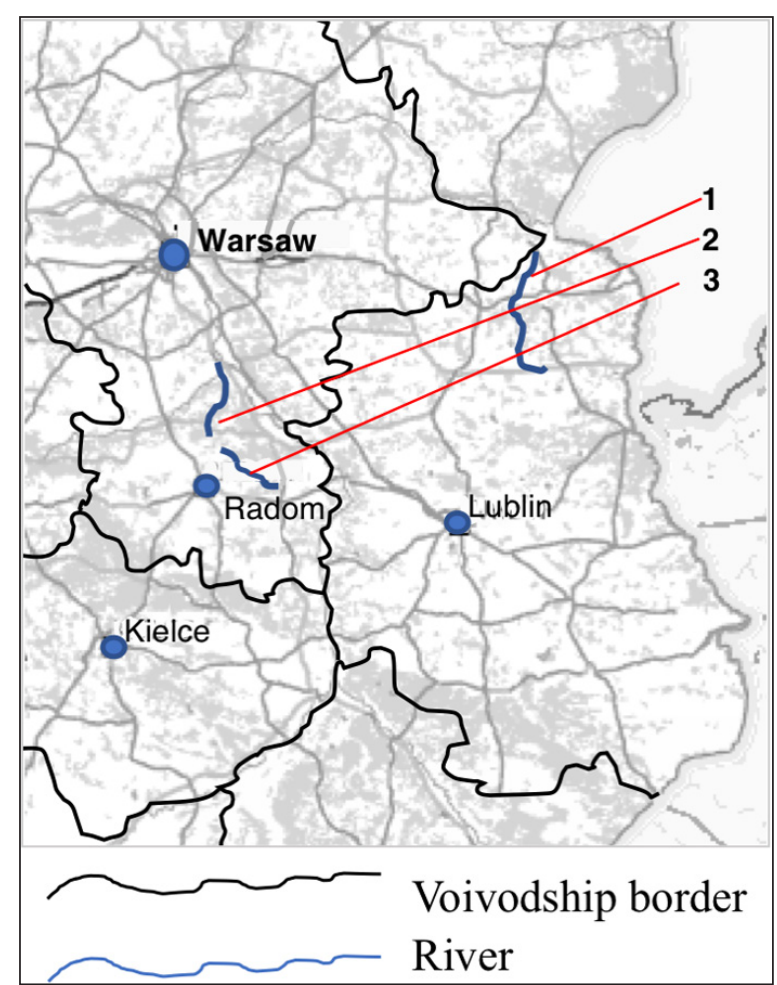

Figure 2. Location of 1 - Zielawa River;

2 - Zagożdżonka River; 3 - Zwoleńka River

and extensively used meadows as well as also marshes. The species composition of the stands is dominated by common pine with some oaks. Within the wetlands, grasslands are settled; therefore, marshy and pine meadows are the dominant habitat type of grasslands.

There are many rare forest species in the forest ecosystems, such as Platanthera bifolia, Platanthera chlorantha, several Carex species and other perennials.

The fauna of the studied area is also characterized by a relative species diversity due to the presence of different types of habitats, such as swamps, wet or dry meadows, forests, copses, and fields where animals breed, feed, and hide. The following animals can be spotted: boar, roe deer, marten, fox, as well as several species of woodpeckers, ore kite, sparrow hawk, hoopoe, and quail.

Zagożdżonka and Zwoleńka are the most important rivers of the Puszcza Kozienicka which are the left tributaries of the Vistula River. Both are draining rivers - the waters from the whole area flow towards them. The courses of these two lowland rivers are meandering; moreover, there are numerous islands, periodically vegetated. The banks of the riverbeds are extensively covered with vegetation. The bedload is predominantly 
a)

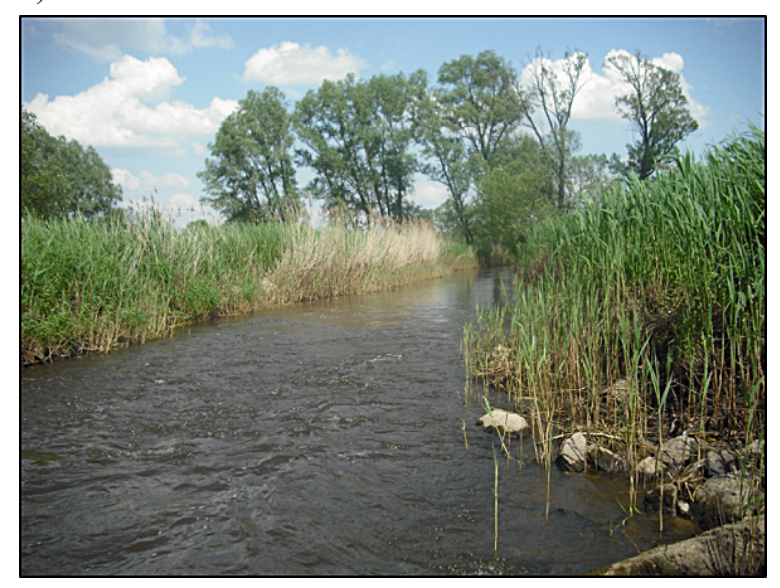

b)

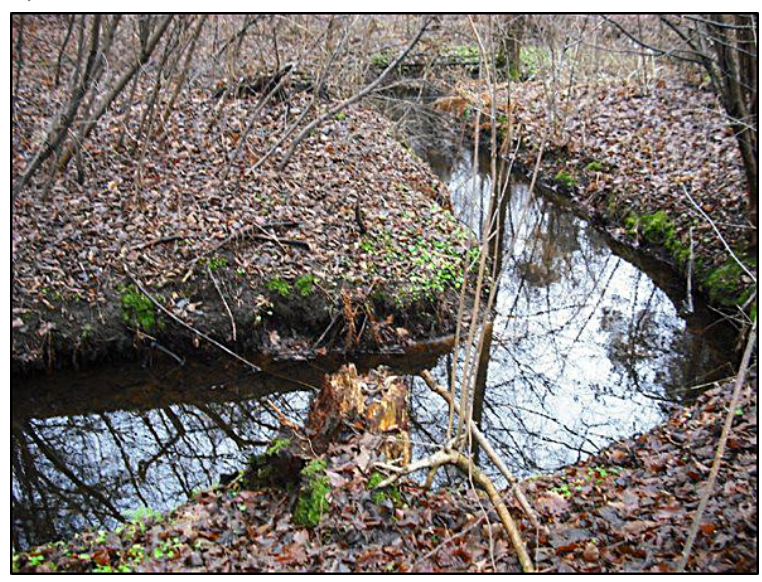

c)

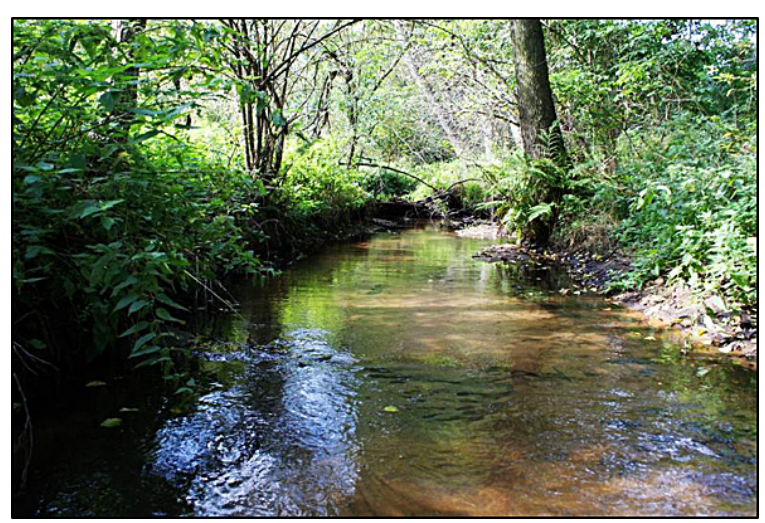

Figure 3. Photographies of the researched rivers within investigated reaches; a) Zielawa River (July 2013);

b) Zagożdżonka River (November 2011); c) Zwoleńka River (May 2012).

represented by sand of different granulation. Due to the lowland river dynamic, the predominance of the deposition process is observed. The surrounding meadows are subject to extensive agricultural use. The adjacent wastelands are overgrown with xerothermic vegetation (Krasowicz et al. 2011). The landscape of the region is characterized by mid-forest marshes overgrown with self-sowing trees, shrubs, herbs, mid-forest meadows and pastures in the river valleys, alder and birch clusters, as well as old ponds, which were unused for about forty years, and are currently undeveloped, undergoing a change into grasslands.

Zwoleńka takes the course through the narrow valley, filled with peat, where natural mud turtle habitats are found. Old riverbeds can be observed along the watercourse. Peat bogs pose a risk of periodic and local pollution of the river. Small pine and alder forests abut on the channel. The area is characterized by eutrophic water bodies, numerous wet meadows and clumps of willow bushes. There is a wealth of species typical of wetland habitats, including the beaver, marsh turtle, weasel, marten, squirrel, hare, European hamster, toad, and newt as well as numerous species of birds.

Zagożdżonka has its source in the Miodne forest complex, flowing through Pionki and Kozienice. For many years, Zagożdżonka has been the basis for some economic branches of the surrounding villages and towns, which can be recognized by the remains of water-powered sawmills. The river valley in the initial section has a greater slope than in the rest of the river. Meanders were formed downstream where the river has a typical lowland character, the valley slope decreases lengthwise and the section is characterized by intact, natural course, where swamps and wet meadows are often located. The valley is overgrown with pines, oaks, spruces, sycamores, ash, maples, alders, birches, lime trees and firs, which are a refuge for various animal species such as beavers, muskrats and otters. The entire area of the Zagożdżonka river belongs to the Natura 2000 network - as a protected area under the so-called "Birds Directive" (colloquial name of 
Directive 2009/147/EC of 30 November 2009 on the conservation of wild birds, which is a consolidated version of the earlier EEC Directive 79/409/EEC of 2 April 1979 on the conservation of wild birds).

The basic hydrological characteristics of the investigated rivers are presented in Table 1 . The average low discharge $S N Q$ and the average longstanding SSQ discharge for Zagożdżonka were assumed according to the hydrological data of Warsaw University of Life Sciences from 1963-2005, the Płachty Stare gauge with the catchment area $A=82.4 \mathrm{~km}^{2}$. The method of hydrological analogy (extrapolation method) was used to estimate the $S W Q$ value (average discharge from the highest annual flows). Jeziorka was examined as a river with analogous flow characteristics (Piaseczno gauge, data from 1951-1970, $\left.A=846 \mathrm{~km}^{2}\right)$. The extrapolation method is used when other methods of analogy cannot be used, the studied profile may be located on the same river as the profileanalogue, as well as on a tributary of this river or another river flowing in its vicinity, as in the case studied (Byczkowski, 1999).

The following data were available:

$\begin{array}{ll}\text { Zagożdżonka: } & \text { Jeziorka } \\ \text { Płachty Stare Gauge } & \text { Piaseczno Gauge } \\ A=82.4 \mathrm{~km}^{2}, & A=846 \mathrm{~km}^{2}, \\ \text { years } 1963-2005 & \text { years } 1951-70 \\ S N Q=0.078 \mathrm{~m}^{3} / \mathrm{s}, & S N Q=0.48 \mathrm{~m}^{3} / \mathrm{s}, \\ S S Q=0.308 \mathrm{~m}^{3} / \mathrm{s}, & S S Q=2.51 \mathrm{~m}^{3} / \mathrm{s}, \\ \text { The lack of } & S W Q=28.6 \mathrm{~m}^{3} / \mathrm{s} .\end{array}$

$S W Q$ value

The calculation of $S W Q$ discharge on Zagożdżonka (Płachty Stare Gauge) by hydrological analogy method (Byczkowski, 1999) was conducted as follows, $\left[\mathrm{m}^{2} / \mathrm{s}\right]$ :

$$
Q=Q_{0}\left(\frac{A}{A_{0}}\right)^{n}
$$

where: $Q$ - flow with the characteristics of interest $\left[\mathrm{m}^{3} / \mathrm{s}\right]$;

$Q_{0}$ - flow of any characteristics in the comparison profile $\left[\mathrm{m}^{3} / \mathrm{s}\right]$;

$A$ - catchment area in the studied profile $\left[\mathrm{km}^{2}\right]$;

$A_{0}$ - catchment area in the comparative profile $\left[\mathrm{km}^{2}\right]$;

The value of the $n$ coefficient is taken depending on the flow characteristics, in the researched case $n=0.84$.

$$
\begin{gathered}
S W Q=S W Q_{0}\left(\frac{A}{A_{0}}\right)^{n}=28.6\left(\frac{82.4}{846}\right)^{0.84}= \\
=4.044 \mathrm{~m}^{3} / \mathrm{s}
\end{gathered}
$$

In order to determine the characteristic flows on the Zwoleńka river, the equation correlating the discharge values of Zagożdżonka in Płachty Stare gauge $\left(Q_{\text {Plachtostare }}\right)$ and Zwoleńka in Siekierka Stara gauge $\left(Q_{\text {SiekierkaStara }}\right)$ was used (Banasik \& Hejduk 2011):

$$
Q_{\text {Siekierkastara }}=1.883 \cdot Q_{\text {Płachtystare }} 0.788
$$

Therefore $S N Q=0.252 \mathrm{~m}^{3} / \mathrm{s} ; S S Q=0.744 \mathrm{~m}^{3} / \mathrm{s}$; $S W Q=5.553 \mathrm{~m}^{3} / \mathrm{s}$ for Zwoleńka River gauge.

Three 500-meters sections were selected within selected rivers (Fig. 4 a,b,c): section 1 on Zielawa; section 2 on Zagożdżonka and section 3 on Zwoleńka.

The examined section of Zielawa underwent many regulatory procedures over the years. The features of today's state of the Zielawa riverbed prove that the principles of technical regulation, which were commonly used in the past, were followed. The analysis of maps indicates the straightening of the riverbed in the whole examined section (Fig. 5b). Field observations proved that the technical procedures had been carried out, such as providing uniform shapes and dimensions

Table 1. Hydrological characteristics summary table

\begin{tabular}{|c|c|c|c|}
\hline River & Zielawa & Zagożdżonka & Zwoleńka \\
\hline Voivodship & Lubelskie & Mazowieckie & Mazowieckie \\
\hline Total length $[\mathrm{km}]$ & 68 & 46 & 230.0 \\
\hline Catchment area $\left[\mathrm{km}^{2}\right]$ & 1146.5 & 568.8 & Siekierka Stara \\
\hline \multicolumn{2}{|c|}{ Characteristic discharges } & $A=186.8 \mathrm{~km}^{2}$ \\
\hline Gauge & Perkowice & Płachty Stare & 0.25 \\
\hline $\mathrm{SNQ}\left[\mathrm{m}^{3} / \mathrm{s}\right]$ & $A=955.2 \mathrm{~km}^{2}$ & $A=82.4 \mathrm{~km}^{2}$ & 0.744 \\
\hline $\mathrm{SSQ}\left[\mathrm{m}^{3} / \mathrm{s}\right]$ & 0.50 & 0.054 & 5.66 \\
\hline $\mathrm{SQW}\left[\mathrm{m}^{3} / \mathrm{s}\right]$ & 2.99 & 0.308 & 4.04 \\
\hline
\end{tabular}

Note: SNQ - the average low discharge; SSQ - the average long-standing discharge; SWQ - average discharge from the highest annual flows. 
a)

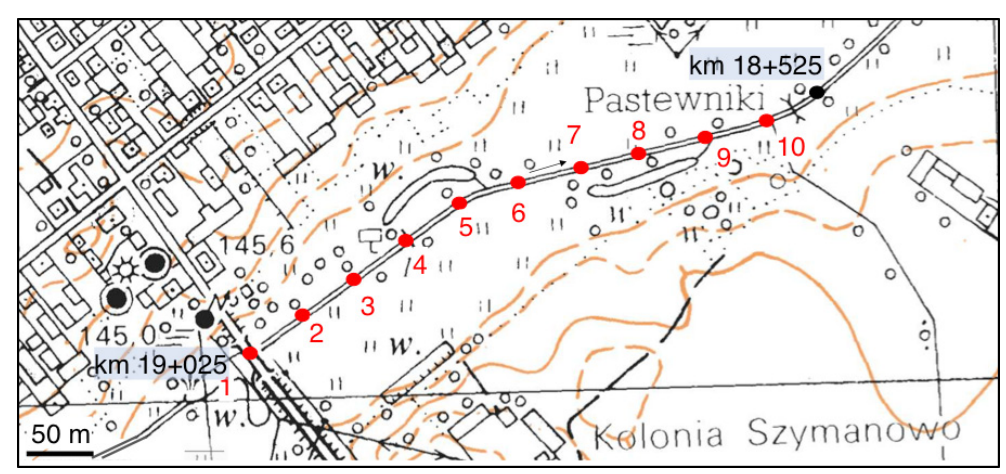

b)

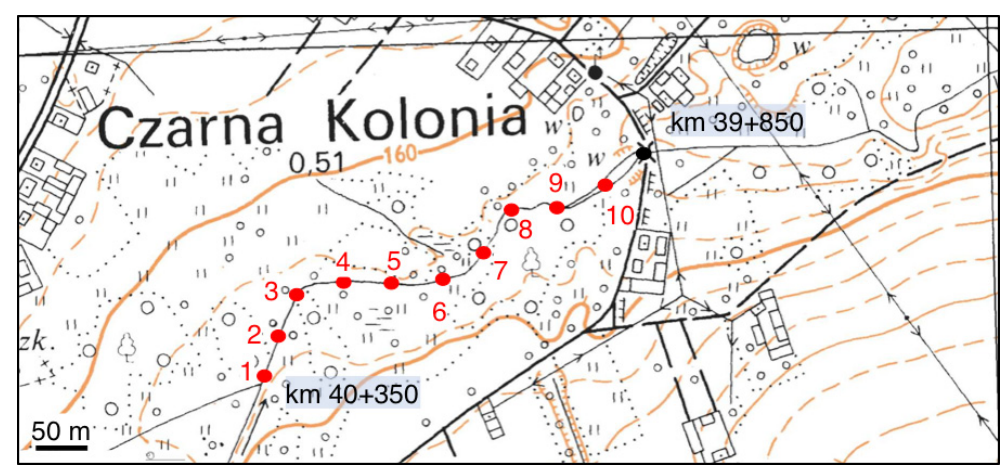

c)

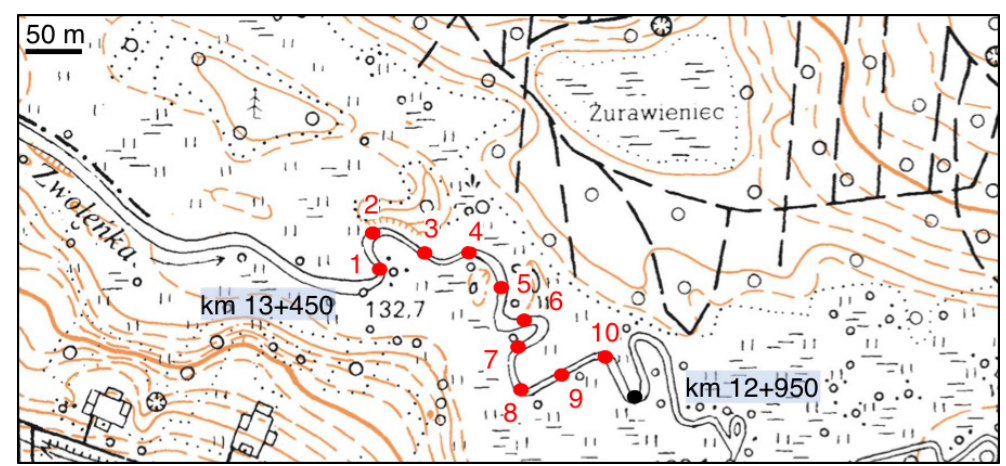

Figure 4. Researched rivers reaches; a) Zielawa River; b) Zagożdżonka River; c) Zwoleńka River.

in the cases of cross-sections (Fig. 5a), irregularity of banks and bottom elimination, the removal of the side channels. On a considerable length of the section, traces of human interference are visible, including mowing of vegetation, fortified banks, often in a poor technical condition, and a small weir in cross section number 4 (rkm $18+$ 825). The adjacent areas are mainly grasslands, and during a May survey, a wealth of fauna species was spotted. Banded demoiselle (damselfly) (Fig. 5d), cockchafer (Fig. 5c), hare, plenty of pheasants, and even roe deer were present.

The chosen Zwoleńka reach has a character of a natural lowland river, with meanders, pools and riffles. The entire section lies within the Natura 2000 nature conservation programme area.
The dominant tree observed during fieldwork is the black alder, with willow bushes in some places. The whole section is densely overgrown with unmanaged reeds, sedges, and tree trunks covered with moss. The beaver activity has been observed here because of bitten trunks and broken small trees (Fig. 5f). The section is located among the forest areas characterized by a high degree of naturalness and little human intervention.

The investigated reach of the Zagożdżonka river is located in the area of Czarna village and runs from the rkm $40+350$, where the river is supplied by the tributary from the adjacent reservoir, down the river to $\mathrm{rkm} 39+850$. Here, the water is slightly piled up with a culvert under the road. The river in the selected section flows among the 
a)

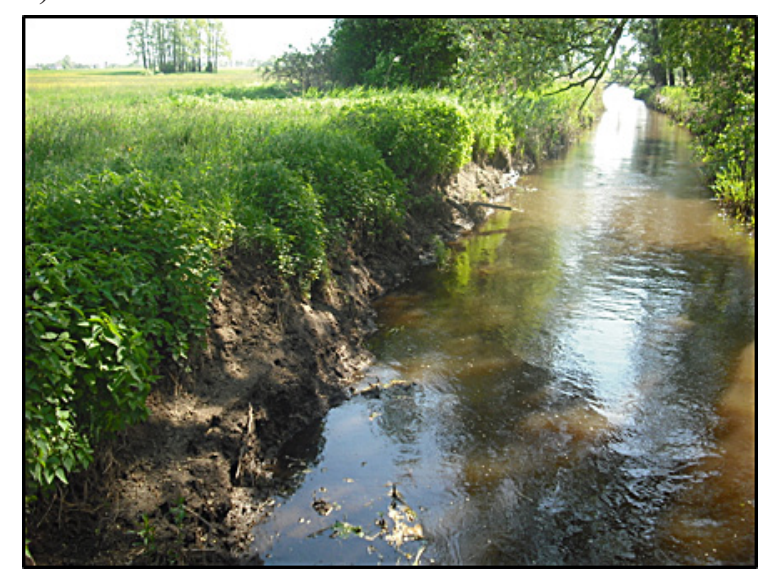

c)

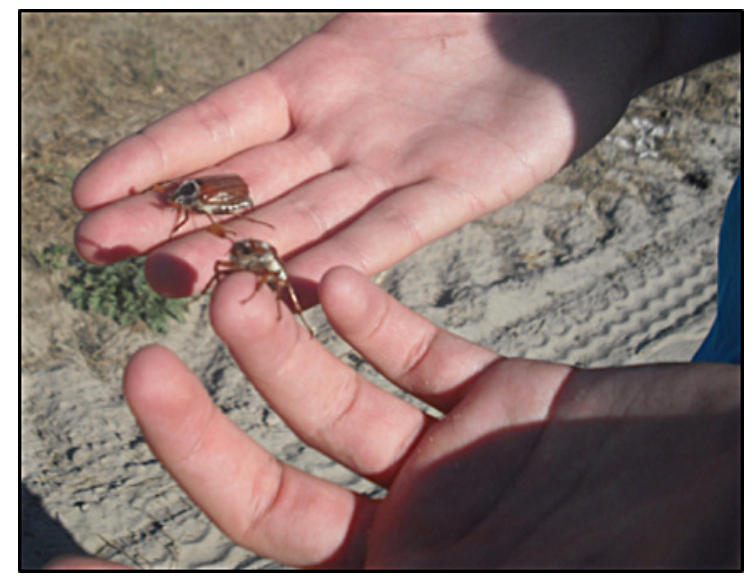

e)

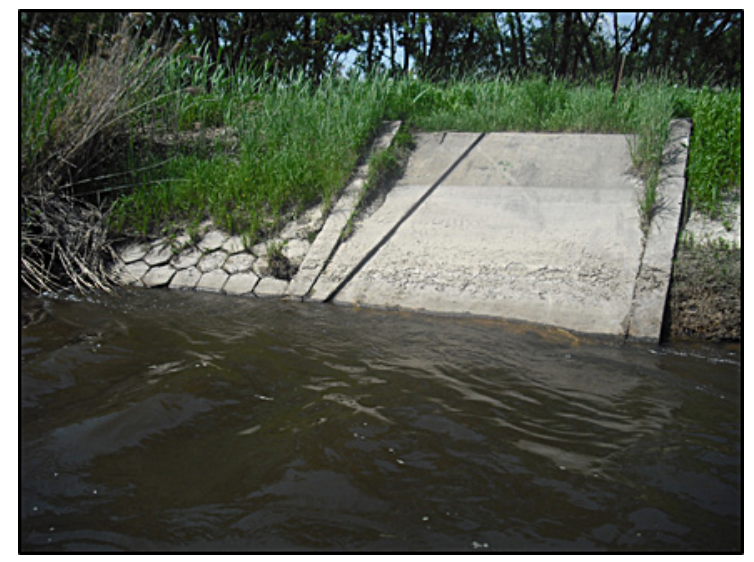

b)

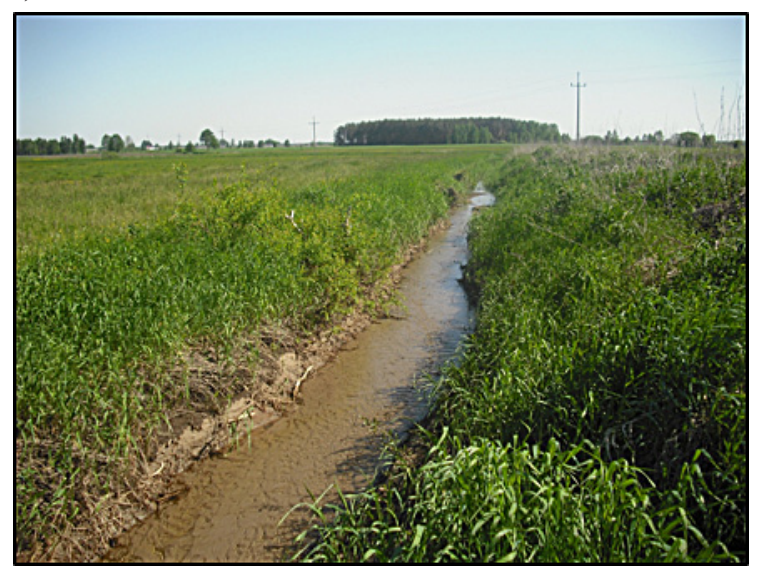

d)

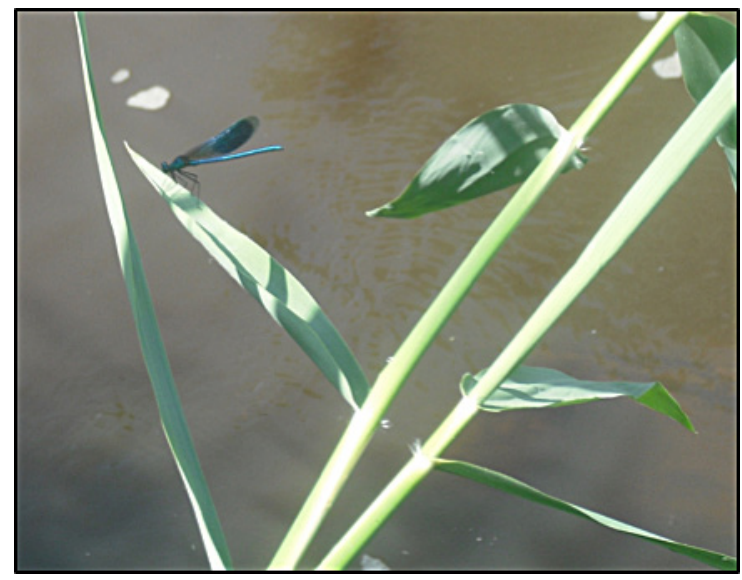

f)

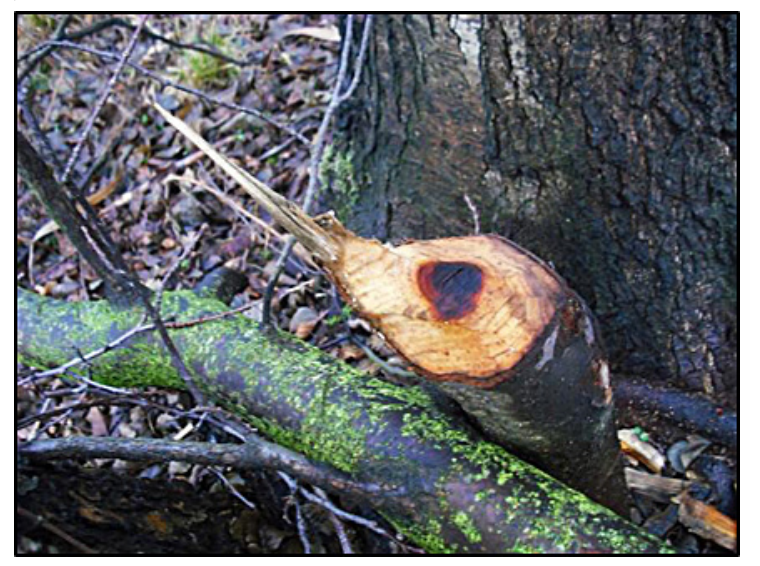

Figure 5. River features observed during field survey, a) unifying the shape of cross-sections as a manifestation of human activity - Zielawa river, b) modified, straightened river course - Zielawa river, c) observed fauna during warmer seasons: cockchafer (Zielawa river) and d) banded demoiselle - male (Calopteryx splendens) (Zwoleńka and Zielawa river), e) bank fortification - Zielawa river, f) the manifestation of beaver activity in the form of bitten trunks and small trees (both Zwoleńka and Zagożdżonka rivers).

alder forests, surrounded by meadows and fields, with some mid-field afforestation. Banks are overgrown with ferns and sedges, systematically mown in most of the studied river sections, as the annual observation shown. Among the trees, pheasants were found during the fieldwork. The inhabitants complain about the harmful activity of beavers causing damage to the cultivated and forest areas, but currently being a protected species, positively influencing the water retention by 
a given habitat. Moreover, in water reservoirs, where the beaver activity is observed, peatbog processes begin. The part of examined section was the subject of river regulation works, such as fascine banks fortification and stone riprap introducing within (Fig. 5e), the reach of rkm 40+190 to $40+540$.

The exact location data and coordinates of the end and beginning of the sections are shown in Table 2. A mobile GPS device was used. The RHS survey data are available for each chosen reach for any season within the period of 2011-2014 (Table 2).
During the field survey, reports were supplemented equipped with a spot-check key. Then, the observations were entered into the River Habitat Survey Toolbox (version 1.3 January 2020, issued by Riverdene Consultancy, according to www.riverhabitatsurvey.org) (Fig. 6). The insights into such hydromorphological state elements are input: predominantly valley form, information about riffles, pools and point bars, artificial features, the material of banks, their modifications and features, land use, bank profile shape, channel dimensions and others are presented.

Table 2. River reach characteristics summary table

\begin{tabular}{|c|c|c|c|}
\hline River & Zielawa & Zagożdżonka & Zwoleńka \\
\hline Section number & 1 & 2 & 3 \\
\hline Section length & 500 & 500 & 500 \\
\hline Number of spot-checks & 11 & 11 & 11 \\
\hline \multicolumn{4}{|c|}{ The spot-check downstream } \\
\hline River kilometer & $18+525$ & $39+850$ & $12+950$ \\
\hline \multirow{2}{*}{ Coordinates } & $N: 51^{\circ} 54^{\prime} 03.88^{\prime \prime}$ & $\mathrm{N}: 51^{\circ} 25^{\prime} 56.12^{\prime \prime}$ & $\mathrm{N}: 51^{\circ} 17^{\prime} 27.69^{\prime \prime}$ \\
\hline & E: $23^{\circ} 10^{\prime} 48.22^{\prime \prime}$ & $\mathrm{E}: 21^{\circ} 27^{\prime} 02.01^{\prime \prime}$ & $E: 21^{\circ} 42^{\prime} 23.14^{\prime \prime}$ \\
\hline \multicolumn{4}{|c|}{ The spot-check upstream } \\
\hline River kilometer & $19+025$ & $40+350$ & $13+450$ \\
\hline \multirow{2}{*}{ Coordinates } & $\mathrm{N}: 51^{\circ} 54^{\prime} 09.48^{\prime \prime}$ & $\mathrm{N}: 51^{\circ} 25^{\prime} 49.26^{\prime \prime}$ & $\mathrm{N}: 51^{\circ} 17^{\prime} 31.97^{\prime \prime}$ \\
\hline & E: $23^{\circ} 11^{\prime} 11.33^{\prime \prime}$ & E: $21^{\circ} 26^{\prime} 41.90^{\prime \prime}$ & $E: 21^{\circ} 42^{\prime} 10.82^{\prime \prime}$ \\
\hline \multicolumn{4}{|c|}{ Research schedule } \\
\hline I survey session: WINTER & February 2013 & January 2012 & January 2012 \\
\hline II survey session: SPRING & March 2013 & May 2012 & May 2012 \\
\hline III survey session: SUMMER & June 2013 & June 2012 & June 2012 \\
\hline IV survey session: AUTUMN & December 2013 & November 2011 & November 2011 \\
\hline
\end{tabular}

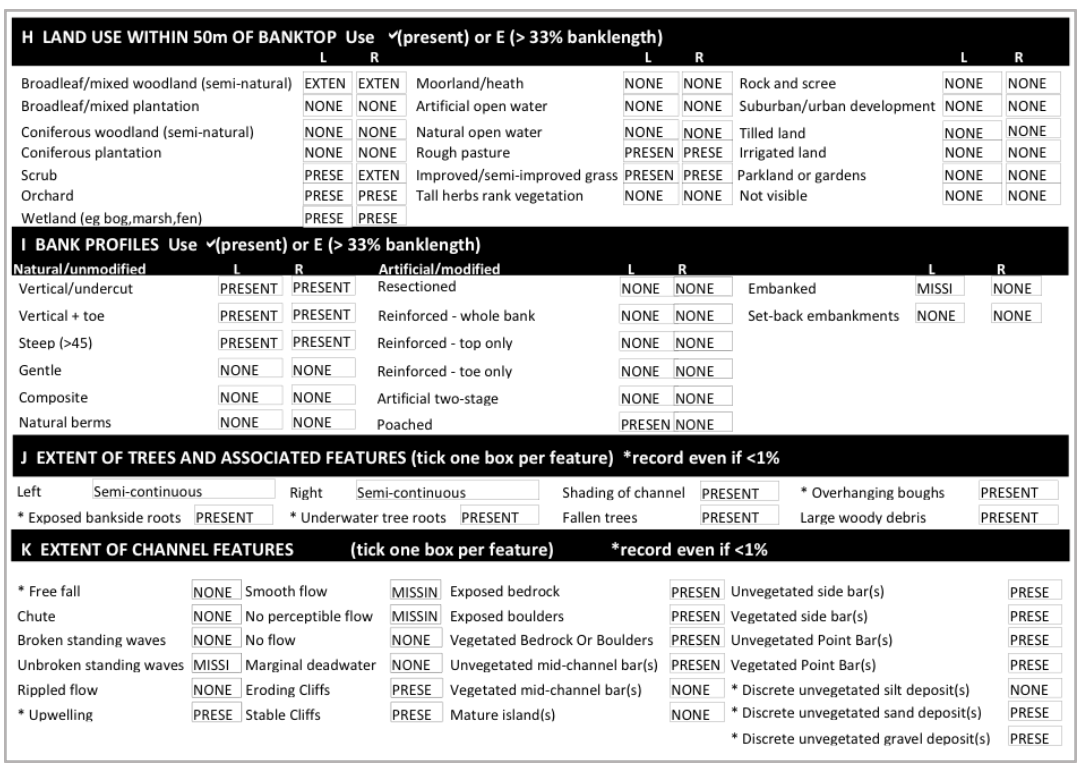

Figure 6. The River Habitat Survey Toolbox input 


\begin{tabular}{|c|c|c|c|c|c|c|}
\hline & \multicolumn{5}{|c|}{ HQA: Indicator value categories } \\
\hline & & $\begin{array}{l}\text { Very natural } \\
(\mathrm{HQA} \geq 57)\end{array}$ & $\begin{array}{c}\text { Natural } \\
(\mathrm{HQA}=50-56)\end{array}$ & $\begin{array}{l}\text { Moderately natura } \\
(\mathrm{HQA}=37-49)\end{array}$ & $\begin{array}{l}\text { Weakly natural } \\
(\mathrm{HQA}=30-36)\end{array}$ & $\begin{array}{l}\text { Little natural } \\
(\mathrm{HQA}<30)\end{array}$ \\
\hline \multirow{5}{*}{ 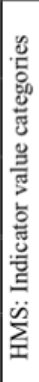 } & $\begin{array}{c}\text { Pristine/ semi-natural } \\
\quad(\text { HMS }=0-2)\end{array}$ & I & II & II & III & III \\
\hline & $\begin{array}{l}\text { Predominantly unmodified } \\
\qquad(\mathrm{HMS}=3-8)\end{array}$ & II & II & III & III & IV \\
\hline & $\begin{array}{l}\text { Obviously modified } \\
\qquad(\mathrm{HMS}=9-20)\end{array}$ & III & III & III & IV & IV \\
\hline & $\begin{array}{l}\text { Significantly modified } \\
\quad(\mathrm{HMS}=21-44)\end{array}$ & III & IV & IV & IV & V \\
\hline & $\begin{array}{l}\text { Severely modified } \\
\quad(H M S \geq 45)\end{array}$ & IV & IV & $\mathbf{v}$ & $\mathbf{v}$ & V \\
\hline
\end{tabular}

Figure 7. Five classes of hydromorphological status based on index values: HQA and HMS (Jusik et al. 2015).

Apart from the presence of plants on banks, bars and those within the channel, such elements describing the vegetation structure could be distinguished: the type of greenery in the adjacent area (scrubs, shrubs, orchard, woodland etc.), vegetation structure uniformity level, bryophytes and lichens participation, free-floating, floating leaved, amphibious, submerged plants appearance and algae presence. Excluding the details describing the location of the test site and the researcher's data, the elements related to the vegetation of the section constitute $47 \%$ of all recorded information (own elaboration).

The obtained HQA and HMS results for each of the sections were recorded in Figure 7, which allows determining the class of hydromorphological condition of the section during the study period. The reference values were taken as Szoszkiewicz et al. 2012 (Jusik et al. 2015), where $\mathrm{I}-\mathrm{V}$ indices hydromorphological class of the reach: high (I), good (II), moderate (III), poor (IV) and bad (V).

\section{RESULTS}

A total of 12 field surveys were made, four for each river section: Zielawa, Zagożdżonka and Zwoleńka. Each subsequent measurement on a given river reach was made during subsequent seasons. The results of the fieldwork were introduced into the River Habitat Survey Toolbox version 1.3 (January 2020), issued by Riverdene Consultancy, which enables calculating the Habitat Quality Assessment (HQA) and Habitat modification Score (HMS) parameters.

The HQA parameters were calculated as a percent of the maximum value, which for Polish conditions is 135. The River Habitat Survey Toolbox program evaluates the degree of river reach modification, providing the result as a range in which the calculated HMS is located (from seminatural to severely modified) (Table 3 ). The annual variability of HQA values is shown in Figure 8 .

The annual variability of the HQA parameter calculation results, expressed in \%, was the highest for the Zwoleńka River section and amounted to $5 \%$ referring to maximal value (Fig. 9). For the Zagożdżonka river section, the variability of the HQA parameter of the order of $4 \%$ was obtained. The lowest annual variability of the HQA parameter was observed for the Zielawa river (2\%).

The section of the Zwoleńka River was classified as the 1st class of the hydromorphological state for the data collected during June (summer), but the values obtained for the remaining seasons of the year allowed to classify the section of the river to the 2nd class of the hydromorphological state. The examined sections of the Zagożdżonka

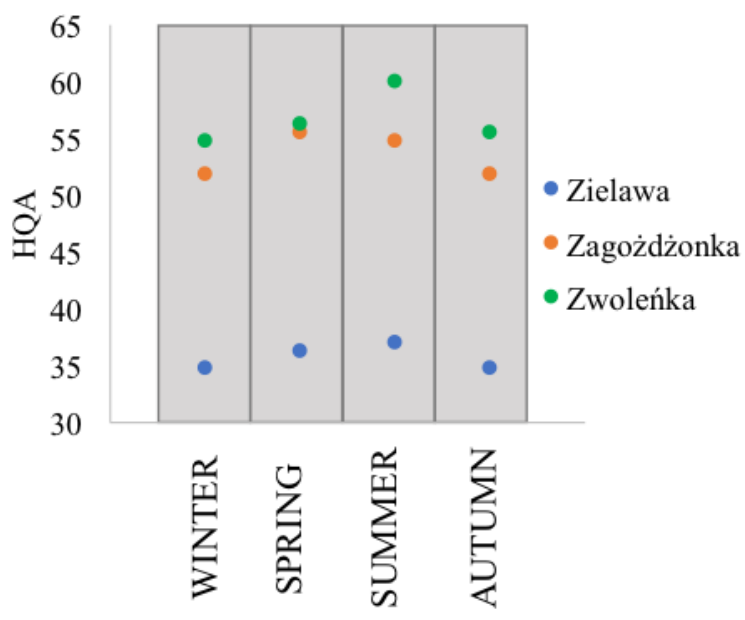

Figure 8. The annual variability of HQA values 
Table 3. HQA and HMS calculation results

\begin{tabular}{|c|c|c|c|c|c|c|}
\hline xRiver & \multicolumn{2}{|c|}{ Zielawa } & \multicolumn{2}{c|}{ Zagożdżonka } & \multicolumn{2}{c|}{ Zwoleńka } \\
\hline Survey session & HQA & HMS & HQA & HMS & HQA & HMS \\
\hline I survey session: & 35 & Severely modified & 52 & Obviously modified & 55 & Semi-natural \\
\hline II survey session: & 36 & Severely modified & 56 & Obviously modified & 56 & Semi-natural \\
\hline III survey session: & 37 & Severely modified & 55 & Obviously modified & 60 & Semi-natural \\
\hline IV survey session: & 35 & Severely modified & 52 & Obviously modified & 56 & Semi-natural \\
\hline
\end{tabular}

\begin{tabular}{|c|c|c|c|c|c|c|}
\hline & \multicolumn{5}{|c|}{ HQA: Indicator value categories } \\
\hline & & $\begin{array}{l}\text { Very natural } \\
(\mathrm{HQA} \geq 57)\end{array}$ & $\begin{array}{c}\text { Natural } \\
(\mathrm{HQA}=50-56)\end{array}$ & \multirow{2}{*}{\begin{tabular}{|c|}
$\begin{array}{c}\text { Moderately natural } \\
(\mathrm{HQA}=37-49)\end{array}$ \\
II
\end{tabular}} & \multirow{2}{*}{$\begin{array}{c}\begin{array}{c}\text { Weakly natural } \\
(\mathrm{HQA}=30-36)\end{array} \\
\text { III }\end{array}$} & \multirow{2}{*}{\begin{tabular}{|c}
$\begin{array}{c}\text { Little natural } \\
(\mathrm{HQA}<30)\end{array}$ \\
III
\end{tabular}} \\
\hline \multirow{5}{*}{ 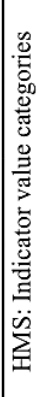 } & $\begin{array}{c}\text { Pristine/ semi-natural } \\
(\mathrm{HMS}=0 \text { - } 2)\end{array}$ & $\underset{\Delta \mathbf{H Q A}_{\mathrm{Z}_{\mathrm{wo}}}}{Q}$ & $\begin{array}{c}I I \\
=5 \%\end{array}$ & & & \\
\hline & $\begin{array}{l}\text { Predominantly unmodified } \\
\qquad(\text { HMS }=3-8)\end{array}$ & II & II & III & III & IV \\
\hline & $\begin{array}{l}\text { Obviously modified } \\
\quad(\text { HMS }=9-20)\end{array}$ & III & III & III & IV & IV \\
\hline & $\begin{array}{l}\text { Significantly modified } \\
(H M S=21-44)\end{array}$ & $\begin{array}{l}\triangle \mathrm{HI} \\
\mathrm{III}\end{array}$ & $\begin{array}{l}\text { Aagożdżonka } \\
\text { IV }\end{array}$ & $4 \%$ & IV & V \\
\hline & $\begin{array}{l}\text { Severely modified } \\
\quad(H M S \geq 45)\end{array}$ & IV & IV & V & 0 & V \\
\hline
\end{tabular}

Figure 9. Hydromorphological class of researched reaches classification

and Zielawa rivers, in spite of the annual differentiation of HQA values, allowed assigning the sections to the III and V class of the hydromorphological condition, respectively.

\section{CONCLUSION}

The analysis demonstrated that the highest class of hydromorphological conditions was reached for the examined section of the Zwolen River (class I during summer, class II during other seasons). Therefore, the hydromorphological state of this section can be classified as between "high" and "good". Such a high class was determined mainly by the insignificant level of human interference in the section's morphology, but also by the richness of the observed fauna and flora. Simultaneously, this section was characterized by the highest annual variation of calculated HQA value, resulting mostly from the degree of vegetation development and observed plant species. For example, a proportion of floating leaf vegetation was different during seasons: in winter, a small proportion was observed, while during summer in some study sections the proportion of floating leaf vegetation was described as "extensive".
The hydromorphological state of the section of the Zagożdżonka river can be classified as 'moderate' on the basis of calculated indicators. The annual variation of the HQA parameter also resulted from the structure and degree of development of vegetation. In this case, for instance, the abundance of the herb species overgrowing the banks in some spot-checks was observed in the summer, while the local vision during autumn demonstrated recent bank mowing, which affected the assessment of uniformity of the structure of coastal vegetation. The worst, "bad", hydromorphological condition has been assigned for the Zielawa river section. Such a poor condition was determined primarily because of the high degree of transformation of the section, i.e., unification of cross-sections, modification of the river course, concrete construction presence, but also a uniform structure of vegetation on the banks in the initial course of the section. Despite the richness of the fauna encountered during the field surveys in any season, the section has reached a relatively low degree of naturalness. The low HQA, with a high transformation level of the section places the Zielawa reach in the fifth class of the hydromorphological status.

The results of the field research analysis for any of 12 surveys indicated a slight differentiation 
of the modifications made to each section during the year. The human activity in the examined period included mainly the maintenance procedures, i.e., mowing of vegetation, anglers' activity, and agricultural practice.

It should be highlighted that a great deal of knowledge about the factors that may influence the hydromorphological state of each river was drawn not only from the local vision but also from direct conversations with the inhabitants of the surrounding villages. For instance, the local anglers helped to identify the fish in the river and indicated the presence of breeding sites of the birds.

It was unequivocally found that the value of the HQA parameter varied during the seasons, and the changes in its numerical value mainly depended on the condition, development level of vegetation, and the number of species observed.

\section{REFERENCES}

1. Able K.W., Manderson J.P., Studholme A. L. 1999. Habitat quality for shallow water fishes in an urban estuary: the effects of man-made structures on growth, Marine Ecology Progress Series 187, 227-235.

2. Armitage P.D., Pardo I. 1995. Impact assessment of regulation at the reach level using macro invertebrate information from mesohabitats, Regulated River: Research and Management 10, 147-158.

3. Banasik K., Hejduk L. 2011. Variability in runoff from a small agricultural catchment - based on long term monitoring data. In: Prediction and Reduction of Diffuse Pollution, Solid Emission and Extreme Flows from Rural Areas - case study of small agricultural catchment (Ed. by K. Banasik, L. Øygarden \& L. Hejduk), Wydawnictwo SGGW, Warszawa.

4. Byczkowski A. 1999. Hydrologia T. I. Wydawnictwo SGGW, Warszawa.
5. Jusik S., Bryl Ł., Przesmycki M. 2015. Najczęstsze błędy w stosowaniu metody RHS. RHS w Polsce, 1-4 [in Polish].

6. Ferreira J., Padua J., Hughes S.J, Cortes R.M., Varandas S., Holmes N., Raven P. 2011. Adapting and adopting River Habitat Survey: Problems and solutions for fluvial hydromorphological assessment in Portugal, Limnetica 30 (2), 263-272.

7. Lacoul P., Freedman B. 2006. Environmental influences on aquatic plants in freshwater ecosystems. Environmental Reviews 14(2), 89-136.

8. Kemp J.L., Harper D.M., Crosa G.A. 2000. The habitat-scale ecohydraulics of rivers, Ecological Engineering 6, 17-29.

9. Kiraga M., Popek Z. 2014. Using the River Habitat Survey method in forecasting effects of river restoration, Annals of Warsaw University of Life Sciences - SGGW. Land Reclamation 46 (2), 125-138.

10. Knehtl M., Petkowska V., Urbanič G. 2017. Is it time to eliminate field surveys from hydromorphological assessments of rivers?-Comparison between a field survey and a remote sensing approach, Ecohydrology 11:e1924, 1-12.

11. Krasowicz S., Oleszek W., Horabik J., Dębicki R., Jankowiak J., Stuczyński T., Jadczyszyn J. 2011. Racjonalne gospodarowanie środowiskiem glebowym Polski, Polish Journal of Agronomy 7, 43-58.

12. Popek Z., Wasilewicz M. 2004. Comparison of morphological characteristics of natural and regulated river reaches based on example of the Wkra River, Przegląd Naukowy Inżynieria i Kształtowanie Środowiska 30, 128-137 [in Polish].

13. Raven P.J., Holmes N.T.H., Dawson F.H., Everard M. 1998. Quality assessment using River Habitat Survey data, Aquatic Conservation: Marine and Freshwater Ecosystems 8, 477-499.

14. Teodosiu C., Barjoveanu G., Teleman D. 2003. Sustainable water resources management 1 . River basin management and the EC Water Framework Directive, Environmental Engineering and Management Journal 2(4), 377-394. 